Vol.8, No.1, pp.1-18, January 2020

Published by ECRTD-UK

Print ISSN: 2053-4019(Print), Online ISSN: 2053-4027(Online)

\title{
TRENDS ON THE CONCEPTION OF COMPETITIVENESS AND MODERN INDUSTRIAL POLICY: THE EMERGENT FIELD OF A NEW SYNTHESIS
}

\author{
Charis Vlados \\ Department of Economics, Democritus University of Thrace \\ School of Business, University of Nicosia \\ Dimos Chatzinikolaou \\ Department of Economics, Democritus University of Thrace
}

\begin{abstract}
The concept of competitiveness and the practice of industrial policy seem to acquire a repositioned meaning and new interest today. We explore how the concept of competitiveness is changing shape and scope and what is the focus of industrial policy both historically and recently in the effort of finding their theoretical convergences and divergences. The findings suggest a move towards an industrial policy that is systemic and integrated since it focuses on enhancing the multilevel competitiveness of the socio-economic system in a unified micro-meso-macro approach. A counter-proposed analysis of the "competitiveness web," which perceives at the centre of the system the evolutionary micro-dynamics of the firm surrounded by co-evolving meso-dynamics and macro-economic and macro-social environments, enhances our understanding towards an "organic" industrial policy that focuses on strengthening the multi-level competitiveness.
\end{abstract}

KEYWORDS: multilevel competitiveness, integrated industrial policy, business dynamics, socioeconomic development, micro-meso-macro analysis, competitiveness web

\section{INTRODUCTION}

This article aims to study the evolving trends in the conceptions of competitiveness and industrial policy in the literature. It will specifically investigate the linkages, contradictions, intertwining, and co-evolution between the concepts of competitiveness and industrial policy. According to Farla (2015), industrial policy can be an instrument to overcome the disturbance caused by market failures, although it is not clear who the beneficiaries of these policies should be. In the context of industrial policy academic debate and practice, industrial policies can be instruments for promoting specific manufacturing sectors (Falck et al., 2011; Pack, 2000) while they can also promote the competitiveness of the entire manufacturing sector (Lall, 2004). Recent studies of industrial policy declare the need for a dialogue between the state and the private sector for identifying and removing the barriers to development (Chang, 2010; Robinson, 2009; Rodrik, 2008). Overall, industrial policy in our days seems to be the process whereby governments aim to play a role in changing the structural characteristics of their economies. This structural change can be any government intervention attempting to change the institutional structure of production, investment, and consumption in favour of sectors that can offer better prospects for economic growth that would not occur in the absence of such intervention (Labory and Bianchi, 2014; Mbate, 2016).

In a similar vein with the different meanings of industrial policy, the concept of competitiveness can bear converging or diverging definitions, something that has led to controversies and opposing 
views. According to the introductory approach of Krugman (1994), competitiveness can be valid when considering the evolution of firms, whereas national or regional entities cannot compete in the sense that firms do; competition between nations and regions is not a zero-sum game, and this is the reason why he insists on the classic concept of productivity. Subsequently, by partly changing his previous positions, Krugman (1994) states that it would be cynical on his part to bypass the debate on competitiveness as a fallacy that only concerns the international trade debate with a different name.

Balkytė and Tvaronavičienè (2010) suggest classifying the existing studies on competitiveness into six categories: Competitiveness of companies, sectors competitiveness, regional competitiveness, national competitiveness, bloc competitiveness, and international competitiveness. According to the World Economic Forum's widely cited definition (The Global Competitiveness Report 2017-2018, 2017, p. 11), competitiveness is "the set of institutions, policies, and factors that determine the level of productivity of an economy, which in turn sets the level of prosperity that the economy can achieve." Garelli (2006, p. 21) applies a more expansive definition since the theory of competitiveness "endeavours to go beyond the analysis of productivity, the accumulation of physical assets, the amassing of wealth, and the increase of power." Garelli argues that benchmarking is central to competitiveness because it tells a company or a nation how its performance measures up with what its competitors are achieving in the same timeframe.

These introductory observations help to clarify the objectives of the present study. Specifically, this article will attempt to explore what are the current trends that exist in the international literature of competitiveness and, correspondingly, what new content seems the concept and practice of industrial policy to acquire recently. Are these trends converging and, if they do so, then what is their content and trends? Is it possible that modern trends in competitiveness can further enrich modern industrial policy? This paper, to answer these research questions, will explore the combined evolution of these two concepts.

\section{METHODOLOGY AND STRUCTURE}

To see how the concepts of competitiveness and industrial policy co-evolve, the following steps of the study demonstrate the methodology for exploring the question:

i. In the first step, the article explores how competitiveness study is changing nowadays.

ii. Second, it examines how the targeting of industrial policy is evolving.

iii. Third, it explores how these two concepts are linked in international literature and what are their convergences and divergences.

iv. In conclusion, based on these findings, there is a methodological counterproposal of competitiveness, which enables a new industrial policy to understand the different ways in which different socio-economic systems can be strengthened.

\section{LITERATURE REVIEW}

\section{The concept of competitiveness is changing shape and scope nowadays}

The concept of competitiveness is in a constant theoretical and practical debate. It involves ambiguity and controversies, encompassing a broad array of definitions and notional contrasts, and complementarities (Bussiere et al., 2014). According to Altomonte and Békés (2016, p. 4), who 
quote the former President of the European Central Bank, a competitive economy is one "in which institutional and macroeconomic conditions allow productive firms to thrive and in turn, the development of these firms supports the expansion of employment, investment and trade." Chiappini (2011) distinguishes between "price competitiveness" and "structural competitiveness," arguing that although prices are an essential element in product trading, they only partially represent a country's ability to impose its products on the world markets. Therefore, structural competitiveness indicates the ability of an economic entity over the medium and long term to differentiate itself from the competition by means other than price.

According to Siudek and Zawojska (2014, pp. 93-94), who present various definitions of competitiveness, the concept of competitiveness "may refer to different levels of aggregation: supranational, national, regional, local, industrial, sectoral, as well as to individual companies." Their research is useful because it can show the evolution of the definitions of competitiveness. Some of these definitions are the following:

- $\quad$ "Bobba, Langer, and Pous (1971): Competitiveness is the ability of nations, regions and companies to generate wealth being the precondition for high wages.

- $\quad$ Scott and Lodge (1985): National competitiveness is a country's ability to create, produce, distribute, and/or service products in international trade while earning rising returns on its resources.

- D'Andrea (1992): Competitiveness is our ability to produce goods and services that meet the test of international competition while our citizens enjoy a standard of living that is both rising and sustainable.

- $\quad$ Ajitabh and Momaya (2004): Competitiveness of a firm is its share in the competitive market.

- Schwab and Sala-i-Martin (2013): Competitiveness is the set of institutions, policies, and factors that determine the level of productivity of a country."

These definitions show indeed a progressive changing perspective in the concept of competitiveness towards an integrated perception that involves, except national or regional entities, the evolution of firms, institutions, and other factors that influence the overall productivity. Therefore, those who define competitiveness must not divide between the different national, sector, and firm levels (Bhawsar and Chattopadhyay, 2015). In this respect, even the widely cited approach to competitiveness by Porter (1990), who depicts national competitiveness to result from six determinants - four internal and two external - has been criticised because should also include the dynamics of globalisation (Cho and Moon, 2000; Dunning, 1993; Rugman, 1992) and because it does not unify sufficiently in the analysis the micro-meso-macro dimensions (Vlados, 2019b).

On the one hand, some conventional approaches to competitiveness perceive the phenomenon from the scope of making a nation to increase its productivity and economic effectiveness and be internationally competitive (Auzina-Emsina, 2014; Gu and Yan, 2017). Industrial competitiveness, on the other hand, focuses on increasing the relative competitive advantages of nations by increasing the national industrial shares (Fetscherin et al., 2012). Finally, firm competitiveness (or micro-level competitiveness), which appears more recently in the literature rather than national or industrial competitiveness, is the capacity of a firm to utilise its competencies and record better performance than the competitors (Díaz-Chao et al., 2016).

In a synthesising and broader perspective (Figure 1), competitiveness can refer to the ability of every organised socio-economic entity (company, organisation, region, or nation) to be superior in results, 
be more efficient, compared with other similar units, in terms of a commonly accepted target. Overall, and within a broader framework, the competitiveness of each socio-economic formation, at every level of analysis (micro-meso-macro, in co-evolutionary terms), is linked to the ability to survive and develop within the evolving conditions of the external socio-economic environment (Vlados and Chatzinikolaou, 2019).

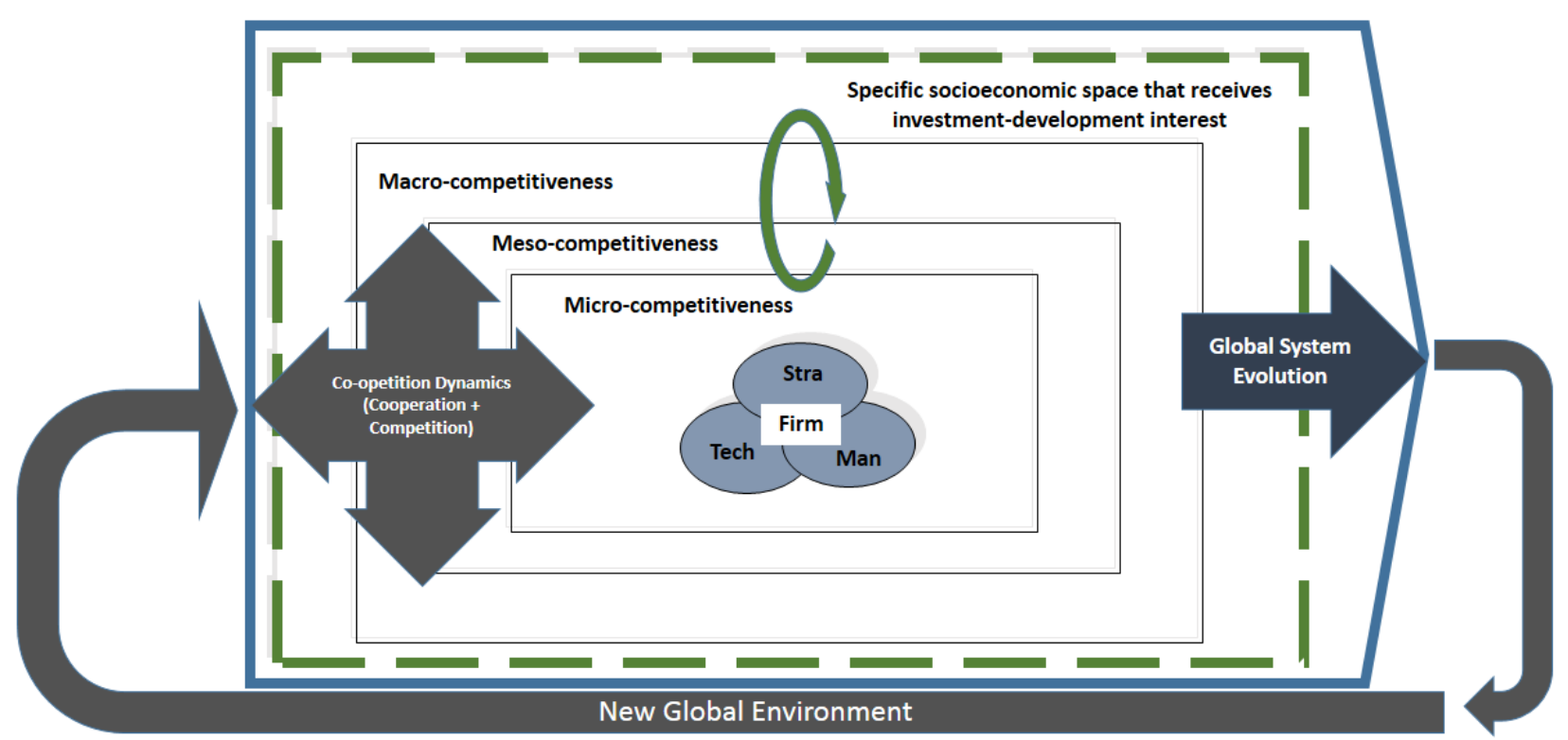

Figure 1. The dynamics of competitiveness of the different socio-economic systems. Based on Vlados and Chatzinikolaou (2019).

First, according to Vlados (2004), the competitiveness potential of every socio-economic system depends on the ability of the firms to innovate based on the ways they manage to synthesise their internal spheres of strategy, technology, and management. All socio-economic organisations respond, explicitly or implicitly, to a complex set of three profound questions to be able to innovate and prosper. In terms of strategy, they are confronting the question: "Where am I, where am I going, how do I get there \& why?" Technology refers to "How do I draw, create, synthesise, spread, and reproduce the means of my work and know-how \& why?" Finally, management asks, "How do I use my available resources \& why?" To the extent that socio-economic organisations of all kinds can effectively combine and synthesise their responses to the three above spheres (strategy, technology, and management), they can innovate and provide a viable response to adaptation requirements posed by the constant change of their external environment, in global terms (Vlados, 2019c).

The level of competitiveness, therefore, of a socio-economic system-of any socio-economic system, in any context of action - is determined by its comparison and competition with the other relevant actors, to the extent that they are capable of producing and harnessing their strategic, technological, and managerial advantages. In this sense, the survival and development of any socioeconomic organisation depend on the ability to have outputs in the market - of every kindcomparatively better than those of competitors - of every level. Competitiveness in this micromeso-macro (Dopfer et al., 2004) approach concerns the ways different socio-economic systems interact and "co-opete" (at the same time, cooperation and competition: Brandenburger and 
Nalebuff, 1996), thus creating the overall evolutionary trajectory of the global system. This "coopetition" means that all socio-economic actors and systems, irrespectively of their level of development and competitiveness, participate to a lesser or greater degree to the shaping of global dynamics and the creation of the new global environment nowadays.

\section{Recent trends of industrial policy focus}

At the level of competitiveness, it is clear that the fragmented competitiveness perspective articulated by different nations, sectors, or firms is not sufficient today, as it seems that a multi-level synthesis is necessary to understand competitiveness. In the past, the practice of policy-making to enhance specific sectors used to happen under the different national industrial policies. This practice of industrial policy to reinforce specific sectors exist since the $19^{\text {th }}$ century (Irwin, 2004), although its popularity is mainly found in the early post-war years, where the "Fordist" system of mass production and consumption is at its peak (Coriat, 1990).

In this context, according to Naudé (2010), there are three phases of industrial policy practice. According to this conceptual distinction, the first phase between 1945 and 1970 featured the growth of industrialisation in the developed countries of the capitalist West. In this Fordist system, where the firms innovate in an augmented way (Vlados, 2019a), there is a perception that governments should intervene in the functioning of markets directly, providing mainly subsidies to some "national champions" (Grabas and Nutzenadel, 2014).

Between 1970 and 2000, the scope of industrial policy goes hand-in-hand with the transforming crisis-development paradigm globally combined with the changing productive model of Fordism to Post-Fordist directions and finds a valid growth response in market liberalisation measures and in the efforts to attract foreign direct investment (Boyer and Durand, 1998). The gradual multinationalisation of US firms primarily is changing the paradigm of the formerly prevailing policy that now aims only at ensuring macroeconomic stability (Baldwin, 1969; Krueger, 1990; Pack, 1993). In this new emerging context of globalisation, from 1980 onwards (Delapierre and Milelli, 1995; Michalet, 2005), the practice of industrial policy is gradually moving towards more "integrated" forms. This change of practice comes in conjunction with the establishment of a postFordist regime, where nation-centred accumulation regimes are beginning to gradually lead to the perception that innovation and technological upgrading should be the critical objectives of a national industrial policy (Vlados, 1996). However, in the current era of crisis and restructuring of globalisation (Andrikopoulos and Nastopoulos, 2015; Lauridsen, 2018; Vlados et al., 2019a), where business innovation is articulated organically at multiple levels of understanding (micro-mesomacro), industrial policy has to grasp the "competitiveness field" primarily (Haar, 2014) rather than by directly subsidising players in different socio-economic systems, at local, regional, and national level (Froy, 2013).

At this point, some definitions of industrial policy, especially in recent years as presented by Warwick (2013, pp. 15-16), are useful for understanding the changing perceptions of industrial policy over time:

- $\quad$ "OECD (1975): Industrial policies are concerned with promoting industrial growth and efficiency.

- Tyson and Zysman (1983): Industrial policy ... means government policy aimed at or motivated by problems within specific sectors. 
- Krugman and Obstfeld (1991): Industrial policy is an attempt by a government to encourage resources to move into particular sectors that the government views as important to future economic growth.

- Rodrik (2004): ... restructuring policies in favour of more dynamic activities generally, regardless of whether those are located within industry or manufacturing per se.

- $\quad$ Pack and Saggi (2006): any type of selective intervention or government policy that attempts to alter the structure of production toward sectors that are expected to offer better prospects for economic growth than would occur in the absence of such intervention."

The above definitions show the actual current tendency of industrial policy to focus, instead of specific sectors, on comprehensive structural interventions and the promotion of dynamic activities in overall terms. After listing these definitions, Warwick (2013, p. 48) argues that the "oldfashioned, selective-reactive, product-market-focused variety of industrial policy" should be replaced by a "soft" industrial policy whose aim is "to develop ways for government and industry to work together to set strategic priorities, deal with co-ordination problems, allow for experimentation, avoid capture by vested interests and improve productivity."

In conclusion, in modern and progressively integrated industrial policy, the micro-level of the firm appears to be one of the most critical features of enhancing the competitiveness of the socioeconomic system (Farole, 2011). In this context, market and government failures are ubiquitous, and the flexibility of industrial policy seems to play a decisive role, depending on the strategic goals of the actual practice of industrial policy.

\section{Combinatorial evolution of the concepts of industrial policy and competitiveness}

How does the concept of industrial policy evolve, and how does it appear to address developments in the field of competitiveness? In the literature of the two disciplines, it seems that there is not yet a study analysing the parallel historical development of the conceptions of competitiveness and industrial policy. After setting the words "competitiveness" and "industrial policy" in the title of the publication as a search criterion at the Scopus database, the search shows 23 results starting from 1976 to 2017. Between the 23 search results, four publications are in different languages than English, and another one refers to a collective volume that coincides with its published introductory section. Therefore, the following literature review includes 18 publications, which are analysed in the following paragraphs in chronological order:

a) In one of the earliest works on the explicit link between competitiveness and industrial policy, Sassoon (1976) examines the Japanese trade flow from 1964 to 1974 in particular industries. The author argues that a country's competitiveness in different sectors corresponds to the success, or failure, in exports. Competitiveness success derives from advantages in costs, quality aspects, efficiency in trading, and others. Based on the foreign investments, the author suggests possible objectives of the Japanese industrial policy in Southeast Asia: Industrial policy tends to take shape in combination with the structural changes of the national economic system. Therefore, the author attempts to link the competitiveness that particular industries demonstrate to the overall national competitiveness. This sectorial-national framework of competitiveness has implications for the national industrial policy, and vice versa.

b) Tiemstra (1994) examines the "competitiveness problem" of the US in conjunction with its industrial policy. The author argues that competitiveness deals with "transition costs" in the sense 
that it means to move from one industrial structure to another. In terms of industrial policy, it is suggested that it is futile using industrial policy to prevent structural change because, in an interconnected world, there are powerful market forces. If a government employs barriers to imports or exports or subsidies to sustain obsolete industries, then it is only causing the costs to rise, and, in the end, the country loses in terms of competitiveness. However, the author concludes that managers need to think in terms of strategy and adopt a long-term perspective, therefore to have in-depth knowledge about their companies and understand not only the requirements of their business but also how other businesses evolve to solve the problem of competitiveness. Therefore, the US needs a business policy instead of a government policy to solve the competitiveness problem.

c) Erber et al. (1997) analyse the successful industrialisation of East and Southeast Asia, together with the "activist" industrial policy set in these countries. The authors suggest that the international competitiveness of enterprises depends on an industrial policy that can enhance the dynamics of specific industries. However, because there are multinational corporations that are adapting actively to the demands of a world market today, a long-term industrial policy must only create the framework conditions for competitive firms. The goal of this "structural industrial policy" is to promote investment in research and development, to spread technical innovations, and establish necessary infrastructures.

d) El- Agraa (1997) compares the UK's "competitiveness policy" and Japan's industrial policy. The author suggests that competitiveness policy differs from the industrial policy because it means the public provision of the environment needed to galvanise into action all industries indiscriminately (domestic or foreign). Therefore, the author notes that the Japanese industrial policy that targeted high growth industries belongs to the past because Japan is emphasising "Thatcherite" economic policies, such as privatisation and deregulation. The article concludes by emphasising the "Japanese pragmatism" in policy-making that is concerned with maintaining an edge in the indefinite future.

e) Hiraoka (1998) argues that globalisation has implications on technological and industrial competitiveness for markets, investments, economic growth, and jobs. More specifically, the author suggests that government policies to enhance national competitiveness are facing a paradigmatic transition because international competitiveness does not depend on large standing armed forces and captive domestic or colonial markets solely. Thus, during the present Information Revolution era, latecomers can catch-up with technological and industrial developments while government policies promoting industrial competitiveness are mainly effective during a catch-up period but can turn debilitating for an advanced nation when they protect specific interests. Education and human resources are critical for technological competitiveness, where fast-paced advances in technology are proving difficult for government oversight of rapidly growing capital, financial, and monetary markets.

f) Wren (2001) analyses the competitiveness policy in the UK, arguing that productivity growth, which can be a source of national competitive advantages, is virtually synonymous with competitiveness. The author suggests that the UK's competitiveness policy draws on the new economic theories of growth and trade and that industrial policy in the UK can be seen as a part of competitiveness policy. This industrial policy focuses primarily on allocative efficiency while, in this new limited role, this industrial policy cannot accomplish stability or redistributive objectives. 
Industrial policy has now shifted from sectoral to horizontal measures, where it employs less broad policy instruments.

g) Coffey (2003) examines the UK's competitiveness policy that gives a great deal of credence to the achievement of competitive advantage in manufacture through dissemination and promotion of best practice production methods. However, the author argues against this policy because this pursuit of "best" practices can undermine strategies for competitiveness by diverting attention from endemic problems of underinvestment in the manufacture and inadequate manufacturing capacity. This development shapes an industrial policy skewed towards maintaining the attractiveness of the UK to "unchallenged" transnational corporations (not confronting properly the decisions of large companies when these come into open conflict with the interests of workers and communities) and, therefore, distracted from the current weaknesses of manufacture.

h) Hafeez Siddiqui and Mujtaba Nawaz Saleem (2010) argue in favour of a "services-led" industrial policy that can complement the structural transition in developing Asian economies by giving an increasing emphasis on competitiveness. The structural reforms of the 1990s were necessary although not sufficient to promote inclusive growth and industrial competitiveness in economies where services prevail since a growth led by services without competitive industries can cause budget problems, deficits, and unemployment. The article recognises a need to fit the current practice of industrial policy to the specific economic structures in developing economies dominated by services.

i) Bosworth et al. (2011) analyse how the EU industrial policy affects rural and peripheral areas. The EU industrial policy that is concerned increasingly with SMEs should help build advantages in rural areas that smaller businesses constitute the majority. However, the goals of Lisbon Agenda towards competitiveness (namely, organisational innovation, open innovation, sharing and exploit innovations, and soft skills such as networking and team working) seem to keep making these rural areas disadvantageous since they lack in inter-business and inter-regional connectivity. The authors suggest that seeking for competitiveness within the industrial policy will keep on making a direct intervention increasingly challenging. In conclusion, the authors are in favour of a "symbiotic entrepreneurship" model that can facilitate businesses to develop forms of competitive advantage that are endogenous and, therefore, are capable of influencing policymaking.

j) Bianchi and Labory (2012) propose a holistic industrial policy in the current crisis to sustain firms' competitiveness and restructuring. Holistic means that we need to take into account the firm's internal and external environments, social and political institutions, and the extent of the market and product requirements. They propose a new industrial policy that includes four levers of industrial development: entitlements, provisions, innovation, and territory. "Entitlements" are for the rights of individuals, "provisions" determine the knowledge, competencies, and resources of individuals, "innovation" is the capacity to apply this new knowledge to production processes, and "territory" is how productive processes in territories can gain from local resources such as infrastructure. These four levers do not substitute each other, and sustainable industrial policy should aim at extending all four by implementing measures at the different levels of government-regional, national, and supranational. 
k) Froy (2013) studies the relation between industrial policy and skills policy by taking the example of the UK's bottom-up industrial policy that intends to build productive local supply chains and, therefore, increase local productivity and competitiveness. The UK's industrial policy is not about "investing in winners" but focuses on providing support to networks of firms while skills policies can contribute to helping businesses access skills they need and, therefore, stimulate a knowledge-based economic development. Increased skill levels are essential for stimulating greater creativity and innovation in the industry. The article concludes that skills policies should be proactive and flexible to the employers' needs to boost productivity and growth, although policymakers should also invest in a broad educational curriculum at the local level.

1) Da Silva and Teixeira (2014) argue that industrial policy is a set of instruments that stimulate specific economic activities and promote structural changes. Therefore, they analyse the structural competitiveness problem of the European periphery struck by the crisis (Greece, Portugal, Spain, and Italy) suggesting that the industrial growth model of these countries has reached its limits, demanding a multidimensional policy approach to find a sustainable path of long-term productivity growth and competitiveness. These countries must address the maintenance of a low-skill bias in the productive structure, the strong relevance of small and micro-sized firms, and the low innovation record and low investments share in GDP to gain international competitiveness.

m) Haar (2014) chooses an approach to competitiveness reflected upon foreign trade performance. By measuring the impact of the patterns of trade for 12 years between Germany and the UK, the author tries to distinguish if international competitiveness justifies or not industrial policies. Although the author claims that micro-level competitiveness means a firm bringing to the market products of high quality that can be produced at a lower cost than the rivals, the approach adopted examines the patterns of international trade and industrial competitiveness. Based on these comparisons, the author finds that supporting framework conditions for innovation and growth, such as infrastructure and research, are probably more useful than policies focused on specific sectors.

n) Mosconi (2015) argues that there is currently an opportunity for a new European industrial policy. By exploring the development of current EU policy, the author suggests how the EU can improve in terms of the competitiveness of its technology policy. The author distinguishes a "Manufacturing Renaissance/New Industrial Policy binomial" that is underway, suggesting that we need both manufacturing and a new industrial policy to be instrumental in promoting necessary structural changes - a proper balance between the State and the Market. The EU must not limit its reforms in the range of macroeconomics, while microeconomics plays an increasingly important role.

o) Popescu et al. (2015) highlight competitiveness and sustainability as central ideas to a modern economic approach to industrial policy. They argue that the EU's industrial policy emphasises short-term measures to reverse the structural problems of competitiveness of the EU industry. According to the European Commission, the objectives of a "consolidated industrial policy" are to ensuring: a) an appropriate legal framework to stimulate new investment in innovation, b) adequate access to finance and capital markets, c) competitive prices for energy and raw materials by improving conditions both domestic and international markets, d) consistent investments in human capital and skills. The authors conclude that Romania has to maintain global competitiveness by applying a complex industrial policy that identifies priority action lines and establishes a program linked with the EU. 
p) Fernández and Pablo-Marti (2016) suggest that trade and supranational integration through regional trade agreements improve the industrial competitiveness of the Middle East and North Africa countries and examine their industrial policies. They argue that free trade promotes competitiveness but also causes pressure for generally small companies in developing countries. They argue that there are no magical prescriptions for industrial strategies but that every country is opting for the best "planification" to achieve a competitive industrial sector, which always requires a cross-sectoral analysis

q) Bačić and Aralica (2017) examine the effects on Croatia's regional competitiveness after implementing a policy based on the EU's "smart specialisation" strategy. This strategy is the EU's horizontal approach to industrial policy that tries to achieve competitive advantage through innovation by emphasising regional firms and institutions since it supports SMEs at a local level through the creation of decentralised business networks and industrial clusters. The authors examine this strategy implemented by Croatia and show that regions with a higher density of high-technology firms already produce relatively more innovation output per capita. In conclusion, they expect that this policy will influence the competitiveness of Croatian regions by directly supporting promising national projects along with other supportive activities such as supporting the establishment of national clusters of competitiveness.

r) Peneder (2017) suggests a "dynamic rationale" of competitiveness and industrial policy that focuses on how to strengthen the socio-economic system's "ability to evolve." The author defines competitiveness as the ability to evolve following a long-term rise of living standards while industrial policy aims to enhance the competitiveness of the broadly defined industry. Contrary to the ubiquitous rationalities of failure, which stem from the orthodox emphasis on allocative efficiency, a dynamic logic of intervention, which derives from the multi-level ontology of "micromeso-macro" evolutionary thinking, targets the functions that an open system must accomplish in order to evolve. To this end, the traditional and "ideologically afflicted" dichotomy between sectoral interventions and mere conditioning framework policies fades away. Therefore, industrial policy is not limited to the objective of structural change but aims for the more comprehensive goal of competitiveness.

Overall, according to the literature review, the connection between the concepts of competitiveness and industrial policy can highlight the following findings:

I. Six out of eighteen publications refer to the implications of the concept of sectoral or industrial competitiveness in industrial policy — and vice versa (Coffey, 2003; Fernández and PabloMarti, 2016; Hafeez Siddiqui and Mujtaba Nawaz Saleem, 2010; Hiraoka, 1998; Sassoon, 1976; Tiemstra, 1994).

II. At the same time, two approaches of industrial policy deal with international competitiveness (Haar, 2014; Hiraoka, 1998), while another two studies discuss the implications of competitiveness policy as a broader concept and practice of industrial policy (El-Agraa, 1997; Wren, 2001).

III. Other approaches that constitute the minority focus in various perceptions of the two concepts, such as international competitiveness of enterprises (Erber et al., 1997) or firms' competitiveness (Bianchi and Labory, 2012) or bottom-up industrial policy for competitiveness (Froy, 2013). The long-term productivity growth and competitiveness (Da Silva and Teixeira, 2014) 
is another goal of industrial policy, whereas global competitiveness (Popescu et al., 2015), competitive advantage through innovation by emphasising regional firms and institutions (Bačić and Aralica, 2017) constitute such goals respectively. Besides, competitiveness and industrial policy constitute a dynamic logic of intervention, which derives from the multi-level ontology of "micromeso-macro" evolutionary thinking and focuses on how to strengthen the socio-economic system's ability to evolve (Peneder, 2017).

IV. Another result of the research derives from the evolution of the two concepts throughout time. The vast majority of publications combining the words competitiveness and industrial policy are from 2010 onwards. Until 2010, the approaches focus mostly on sectoral or industrial competitiveness issues (Coffey, 2003; Hiraoka, 1998; Sassoon, 1976; Tiemstra, 1994). That is, it seems that from 2010 onwards (within the current era of crisis and restructuring of globalisation), the concepts of industrial policy and competitiveness get more complicated.

V. Besides, a "unifying" character of industrial policy, especially after 2010, is another observed pattern. Industrial policy is not limited to the objective of structural change but aims at a more comprehensive goal of competitiveness (Peneder, 2017). Industrial policy is now combined with concepts such as "holistic" (Bianchi and Labory, 2012) or competitiveness and sustainability (Popescu et al., 2015). Industrial policy can also be a bottom-up policy that can boost local productivity and competitiveness (Froy, 2013), a supporting instrument for general conditions for growth and innovation (Haar, 2014), or a horizontal approach to achieve competitive advantage through innovation (Bačić and Aralica, 2017).

VI. In this context, the industrial policy of enhancing competitiveness seems to be moving towards a more comprehensive approach to the socio-economic system, especially after 2010. Four out of eleven post-2010 publications view competitiveness as a fuller phenomenon and do not focus on partial aspects. Seeking for competitiveness within the industrial policy will continue to make a direct intervention in specific sectors more challenging (Bosworth et al., 2011), while industrial policy should seek a sustainable path of long-term productivity growth and competitiveness (Da Silva and Teixeira, 2014; Popescu et al., 2015). A "micro-meso-macro" understanding of the socioeconomic system's ability to evolve is crucial for development (Peneder, 2017).

Overall, the findings converge to the idea that the concepts of competitiveness and industrial policy acquire an ever-tighter and complementary nature progressively. In the past, the industrial policy of enhancing competitiveness has been primarily a matter of sector-specific interventions; today, however, the industrial policy objective becomes increasingly complex, strongly combinatory, and claims an explicit strategic content.

\section{CONCLUSIONS AND DISCUSSION: THE "COMPETITIVENESS WEB" AS A COUNTERPROPOSAL OF AN INTEGRATED AND ORGANIC INDUSTRIAL POLICY TO FOSTER MULTI-LEVEL COMPETITIVENESS}

This article explored how the concepts of competitiveness and industrial policy co-evolve and transform throughout recent history, and how international literature perceives and connects them analytically. The findings suggest that the goal of sectoral competitiveness in industrial policy is the most used element until this day, although new approaches to the phenomenon suggest a more complex relationship, especially after 2010 (that is, within the current era of crisis and restructuring of globalisation). To this end, the concept of industrial policy seems to move towards an integrated perception and practice than simple sectoral support or limited horizontal framework policies. 
Print ISSN: 2053-4019(Print), Online ISSN: 2053-4027(Online)

Industrial policy has now a flexible and strategic developmental target that enables socio-economic systems to evolve.

Moreover, socio-economic development does not mean just growth: development means parallel quantitative and qualitative dialectical transitions (Vlados et al., 2019b). As Peneder (2017) implies, the competitiveness of an open and evolving socio-economic system unfolds at all levels, either the micro-firm level, the meso-level of structural balances/imbalances, or the macro-level of totalising dynamics. A new industrial policy has to study both the current instances of structures where it "leans" as well as the past generative mutations that have led to the current structural balance. Therefore, industrial policy, apart from a means of strengthening the industry, is also a "unifying" policy that takes into account all the socio-economic ingredients that produce and reproduce competitiveness at all spatial levels.

These findings can lead to counter-propose an analytical enrichment of an industrial policy to foster competitiveness by applying an approach of the socio-economic system as a "competitiveness web" (Figure 2).

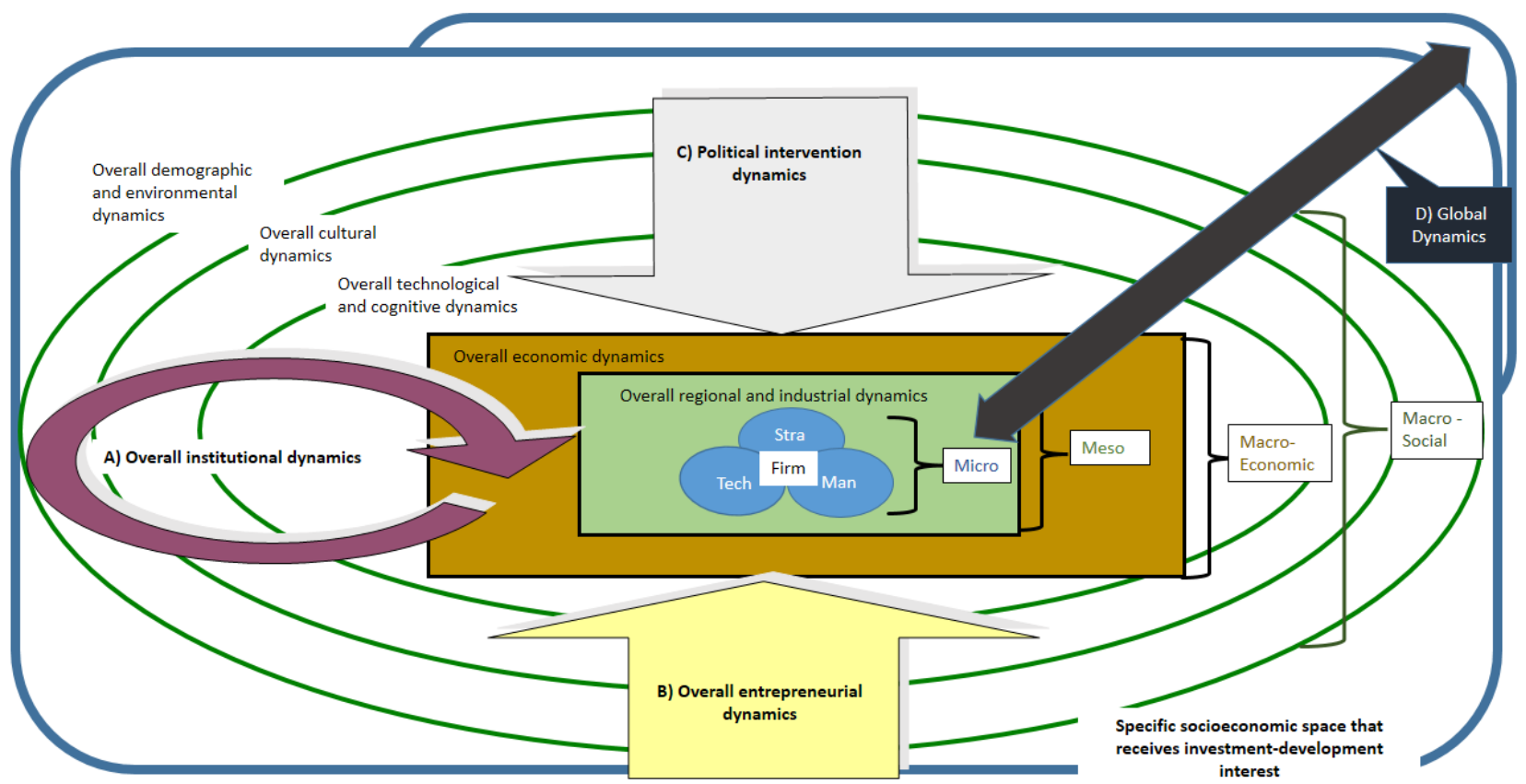

Figure 2. The "competitiveness web." Based on Vlados (2006).

This scheme of the "competitiveness web" shows first the dynamics of entrepreneurship at the centre of the socio-economic system as the firms, which are synthesising the spheres of strategy, technology, and management (Stra.Tech.Man synthesis) internally, lead to innovation that redefines the entire system and its competitiveness potential. The micro-level of the firm and the hosting industry, the meso-level that encompasses inter-sectoral economic dynamics, and the macroeconomic and macro-social level, constitute together a "web" in which a systemic effect has direct or indirect effects on the involving subsystems. All subsystems of this network are in a continuous co-evolution of organic type. Disruptions or crises that occur at any level of space (local, national, and supranational) in any of these subsystems diffuse into the competitiveness web. The same condition also applies in the articulation of positive developments in one or more of these 
subsystems. Improvements to the individual subsystems (that is, through positive spillovers), can lead the overall system to a strengthening of its competitive potential and development prospects. Consequently, the competitiveness web perspective must be understood as an ever-evolving socioeconomic reality that involves constant structural changes that change the nature of the different socio-economic systems through a process we could say is of "biological type".

This approach follows in practice to some extent Nelson and Winter's (1982) interpretation of the content of evolutionary economics, where the biological approach of economic systems rejects the neoclassical point of view that treats the firm and the rest of the economic actors as timeless inputoutput transformers. Specifically, the biological interpretation of the economy argues that "socioeconomic organisms" are governed by the potential for adaptation, which simultaneously transforms the internal and external organisational environment at all levels (individual-firm, local, national, and supranational).

Therefore, this competitiveness web creates a framework of interest for investment and development shaped by four dynamics that force the system to change structurally: institutional, entrepreneurial, policy-interventionist, and global dynamics are altering the system and themselves constantly. Of course, each dynamic in today's era of globalisation interacts and receives feedback from other spatialised "competitiveness webs." As a result, a new industrial policy of enhancing competitiveness by recognising the innovative potential of the firms of the socio-economic system in terms of Stra.Tech.Man can design targeted intervention policies that will not focus exclusively on the "physiognomy" of the different sectors. An integrated industrial policy of enhancing competitiveness is, in fact, a means of creating developmental niches (such as clusters and business ecosystems), which seem to receive and give cross-sectoral flows in the modern era of globalisation and not confined to their national contours.

In conclusion, the limitation of the present study is evident in the sense that industrial policy requires, as with any economic policy, the will to implement it, and therefore this article is only able to present a re-positioned framework of conceptualising the industrial policy, which is integrated and cross-spatial and aims to enhance multilevel competitiveness. Besides, the approach of the "competitiveness web" could be exploited further to the extent that it functions as an index of competitiveness by taking into account the different "micro-meso-macro-economic" and "macrosocial" dimensions. It could use a combination of qualitative and quantitative indicators and measurements in a way that allows policy-makers to develop targeted intervention policies at local/inter-local, regional/inter-regional, and national/international level.

\section{References}

Ajitabh, A., and Momaya, K., 2004. Competitiveness of firms: review of theory, frameworks and models. Singapore Management Review, 26(1), pp. 45-61.

Altomonte, C., and Békés, G. (Eds.), 2016. Measuring competitiveness in Europe: resource allocation, granularity and trade, Bruegel blueprint series. Bruegel, Brussels, Belgium.

Andrikopoulos, A., and Nastopoulos, Ch., 2015. Crisis and realism, Book published in Greek under

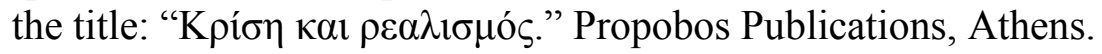

Auzina-Emsina, A., 2014. Labour productivity, economic growth and global competitiveness in post-crisis period. Procedia - Social and Behavioral Sciences, 19th International Scientific Conference "Economics and Management 2014 (ICEM-2014)," November, 156, pp. 317321. https://doi.org/10.1016/j.sbspro.2014.11.195 
European Journal of Business and Innovation Research

Vol.8, No.1, pp.1-18, January 2020

Published by ECRTD-UK

Print ISSN: 2053-4019(Print), Online ISSN: 2053-4027(Online)

Bačić, K., and Aralica, Z., 2017. Regional competitiveness in the context of "New industrial policy" - The case of Croatia. Zbornik Radova Ekonomskog Fakultet au Rijeci, 35(2), pp. 551-582. https://doi.org/10.18045/zbefri.2017.2.551

Baldwin, R.E., 1969. The case against infant-industry tariff protection. Journal of Political Economy, 77(3), pp. 295-305. https://doi.org/10.1086/259517

Balkytè, A., and Tvaronavičienè, M., 2010. Perception of competitiveness in the context of sustainable development: facets of "sustainable competitiveness." Journal of Business Economics and Management, 11(2), pp. 341-365. https://doi.org/10.3846/jbem.2010.17

Bhawsar, P., and Chattopadhyay, U., 2015. Competitiveness: review, reflections and directions. Global Business Review, 16(4), pp. 665-679. https://doi.org/10.1177/0972150915581115

Bianchi, P., and Labory, S., 2012. Conceptualisations, relationships and trends between innovation, competitiveness and development: Industrial policy beyond the crisis, in: Cooke, P., Parrilli, M.D., Curbelo, J.L. (Eds.), Innovation, global change and territorial resilience. Edward Elgar, Cheltenham, UK; Northampton, MA, pp. 295-312. https://doi.org/10.4337/9780857935755.00023

Bobba, F., Langer, W., and Pous, J., 1971. Bericht über die WETTBEWERBSFÄHIGKEIT der Europäischen Gemeinschaf. Brussels, Belgium.

Bosworth, G., Dana, L.P., and McElwee, G., 2011. EU industrial policy and competitiveness in rural SMEs. International Journal of Entrepreneurship and Small Business, 14(3), pp. 391-405. https://doi.org/10.1504/IJESB.2011.042760

Boyer, R., and Durand, J.-P., 1998. L'après-fordisme. Syros, Paris.

Brandenburger, A., and Nalebuff, B., 1996. Co-opetition: a revolution mindset that combines competition and cooperation. Doubleday, New York.

Bussiere, M., Gaulier, G., and Jean, S., 2014. La compétitivité-prix explique-t-elle les performances à l'exportation de la France et de ses partenaires? La Lettre du CEPII, (349).

Chang, H.-J., 2010. Industrial policy: Can we go beyond an unproductive confrontation? (No. 2010/1), Working Papers. Turkish Economic Association.

Chiappini, R., 2011. Comment mesurer la compétitivité structurelle des pays dans les équations d'exportation? L'Actualité économique, 87(1), pp. 31-57. https://doi.org/10.7202/1006338ar

Cho, D.-S., and Moon, H.-C., 2000. From Adam Smith to Michael Porter: evolution of competitiveness theory. World Scientific, New Jersey; London; Singapore; Hong Kong. https://doi.org/10.1142/9789812385222

Coffey, D., 2003. Best practice manufacture as industrial policy: Lean production, competitiveness and monopoly capitalism, in: Coffey, D., Thornley, C. (Eds.), Industrial and labour market policy and performance: issues and perspectives. Routledge, London, pp. 45-61. https://doi.org/10.4324/9780203986721

Coriat, B., 1990. L'atelier et le robot: essai sur le fordisme et la production de masse à l'âge de l'électronique. C. Bourgois, Paris.

Da Silva, E.G., and Teixeira, A.A.C., 2014. Introduction: structural change, competitiveness and industrial policy, in: Teixeira, A.A.C., Da Silva, E.G., Mamede, R.P. (Eds.), Structural change, competitiveness and industrial policy: painful lessons from the European periphery. Routledge, London; New York, pp. 3-9.

D'Andrea, T., 1992. Who's bashing whom: trade conflict in high technology industries. Institute for International Economics, Washington DC.

Delapierre, M., and Milelli, C., 1995. Les firmes multinationales. Vuibert, Paris. 
European Journal of Business and Innovation Research

Vol.8, No.1, pp.1-18, January 2020

Published by ECRTD-UK

Print ISSN: 2053-4019(Print), Online ISSN: 2053-4027(Online)

Díaz-Chao, Á., Sainz-González, J., and Torrent-Sellens, J., 2016. The competitiveness of small network-firm: A practical tool. Journal of Business Research, Designing implementable innovative realities, 69(5), pp. 1769-1774. https://doi.org/10.1016/j.jbusres.2015.10.053

Dopfer, K., Foster, J., and Potts, J., 2004. Micro-meso-macro. Journal of Evolutionary Economics. 14(3), pp. 263-279. https://doi.org/10.1007/s00191-004-0193-0

Dunning, J.H., 1993. Internationalizing Porter's diamond. Management International Review; Wiesbaden, 33(2), pp. 7-15.

El- Agraa, A.M., 1997. UK competitiveness policy vs. Japanese industrial policy. The Economic Journal, 107(444), pp. 1504-1517. https://doi.org/10.1111/j.1468-0297.1997.tb00061.x

Erber, G., Hagemann, H., and Seiter, S., 1997. Global competitiveness: Industrial policy in the performance of Asia and Europe. Journal of Contemporary Asia, 27(3), pp. 338-355. https://doi.org/10.1080/00472339780000201

Falck, O., Gollier, C., and Woessmann, L., 2011. Industrial policy for national champions. MIT Press, Cambridge, MA. https://doi.org/10.7551/mitpress/9780262016018.001.0001

Farla, K., 2015. Industrial policy for growth. Journal of Industry, Competition and Trade, 15(3), pp. 257-282. https://doi.org/10.1007/s 10842-014-0183-3

Farole, T., 2011. Trade and industrial policy 2.0-facilitating firm-level competitiveness and economy-wide adjustment. Presented at the Bölgesel Kalkınma ve Yönetişim Sempozyumu Sanayi Politikasının Yönetişimi, tepav, Ankara, pp. 43-60.

Fernández, M.T.F., and Pablo-Marti, F., 2016. Industrial competitiveness in MENA countries: current strategic directions of industrial policy, in: Erdodu, M., Christiansen, B. (Eds.), Handbook of research on comparative economic development perspectives on Europe and the MENA region. IGI Global, Hershey, Pennsylvania, pp. 152-171. https://doi.org/10.4018/978-1-4666-9548-1.ch008

Fetscherin, M., Alon, I., Johnson, J.P., and Pillania, R.K., 2012. Export competitiveness patterns in Indian industries. Competitiveness Review: An International Business Journal, 22(3), pp. 188-206. https://doi.org/10.1108/10595421211229637

Froy, F., 2013. Global policy developments towards industrial policy and skills: skills for competitiveness and growth. Oxford Review of Economic Policy, 29(2), pp. 344-360. https://doi.org/10.1093/oxrep/grt020

Garelli, S., 2006. Top class competitors: how nations, firms, and individuals succeed in the new world of competitiveness. John Wiley \& Sons, Chichester, England; Hoboken, NJ.

Grabas, C., and Nutzenadel, A., 2014. Industrial policy in Europe after 1945: wealth, power and economic development in the Cold War. Palgrave Macmillan, Basingstoke. https://doi.org/10.1057/9781137329905

Gu, W., and Yan, B., 2017. Productivity growth and international competitiveness. Review of Income and Wealth, 63(S1), pp. S113-S133. https://doi.org/10.1111/roiw.12254

Haar, L.N., 2014. Do patterns of trade and international competitiveness support the case for industrial policy? Policy Studies, 35(3), pp. 221-245. https://doi.org/10.1080/01442872.2014.886680

Hafeez Siddiqui, S., and Mujtaba Nawaz Saleem, H., 2010. Services- led industrial policy for inclusive growth and competitiveness. Competitiveness Review: An International Business Journal, 20(2), pp. 166-181. https://doi.org/10.1108/10595421011029875

Hiraoka, L.S., 1998. Introduction: industrial policy and technological competitiveness. International Journal of Technology Management, 15(6-7), pp. 523-525.

Irwin, D.A., 2004. The aftermath of Hamilton's "Report on Manufactures." The Journal of Economic History, 64(3), pp. 800-821. https://doi.org/10.1017/S0022050704002979 
European Journal of Business and Innovation Research

Vol.8, No.1, pp.1-18, January 2020

Published by ECRTD-UK

Print ISSN: 2053-4019(Print), Online ISSN: 2053-4027(Online)

Krueger, A.O., 1990. Government failures in development. The Journal of Economic Perspectives, 4(3), pp. 9-23. https://doi.org/10.1257/jep.4.3.9

Krugman, P., 1996. Making sense of the competitiveness debate. Oxford review of economic policy, 12(3), pp. 17-25. https://doi.org/10.1093/oxrep/12.3.17

Krugman, P., 1994. Competitiveness: a dangerous obsession. Foreign Affairs, 73(2), pp. $28-44$. https://doi.org/10.2307/20045917

Krugman, P., and Obstfeld, M., 1991. International economics: theory and policy, Pearson-Addison Wesley, New York.

Labory, S., and Bianchi, P., 2014. The institutional framework of industrial policies (No. 2014203), Working Papers. University of Ferrara, Department of Economics.

Lall, S., 2004. Reinventing industrial strategy: the role of government policy in building industrial competitiveness (No. 28), G-24 Discussion Papers. United Nations Conference on Trade and Development.

Lauridsen, L.S., 2018. New economic globalization, new industrial policy and late development in the 21st century: A critical analytical review. Development Policy Review, 36(3), pp. 329346. https://doi.org/10.1111/dpr.12299

Mbate, M., 2016. Structural change and industrial policy: A case study of Ethiopia's leather sector. Journal of African Trade, 3(1), pp. 85-100. https://doi.org/10.1016/j.joat.2017.01.001

Michalet, C.-A., 2005. Qu'est-ce que la mondialisation?: petit traité à l'usage de ceux et celles qui ne pas encore s'il faut être pour ou contre, La Découverte Poche / Essais. La Découverte, Paris.

Mosconi, F., 2015. The new European industrial policy: global competitiveness and the manufacturing renaissance. Routledge, London; New York. https://doi.org/10.4324/9781315761756

Naudé, W., 2010. Industrial policy: old and new issues (Working Paper No. 2010, 106). Working paper, World Institute for Development Economics Research.

Nelson, R., Winter, S., 1982. An evolutionary theory of economic change. The Belknap Press of Harvard University Press, Cambridge, MA; London, UK.

OECD, 1975. Objectives and instruments of industrial policy: a comparative study. OECD, Paris.

Pack, H., 2000. Industrial policy: growth elixir or poison? The World Bank Research Observer, 15(1), pp. 47-67. https://doi.org/10.1093/wbro/15.1.47

Pack, H., 1993. Productivity and industrial development in sub-Saharan Africa. World Development, 21(1), pp. 1-16. https://doi.org/10.1016/0305-750X(93)90133-T

Pack, H., and Saggi, K., 2006. Is there a case for industrial policy? A critical survey. The World Bank Research Observer, 21(2), pp. 267-297. https://doi.org/10.1093/wbro/lk1001

Peneder, M., 2017. Competitiveness and industrial policy: from rationalities of failure towards the ability to evolve. Cambridge Journal of Economics, 41(3), pp. 829-858. https://doi.org/10.1093/cje/bew025

Popescu, V.A., Popescu, G.N., and Popescu, C.R., 2015. Competitiveness and sustainability - a modern economic approach to the industrial policy. Metalurgija, 54(2), pp. 426-428.

Porter, M., 1990. The competitive advantage of nations. Harvard Business Review: International Business, March-April, pp. 73-91.

Robinson, J.A., 2009. Industrial policy and development: a political economy perspective. Presented at the 2009 World Bank ABCDE Conference, Seoul.

Rodrik, D., 2008. Normalizing industrial policy (Commission on Growth and Development No. Working Paper No. 3). World Bank, Washington, DC. 
Rodrik, D., 2004. Industrial policy for the twenty-first century (No. KSG Working Paper No. RWP04-047). Harvard University, Cambridge MA. https://doi.org/10.2139/ssrn.617544

Rugman, A.M., 1992. Porter takes the wrong turn. Business quarterly, 56(3), pp. 59-64.

Sassoon, J., 1976. Trends of competitiveness and industrial policy of Japan in Southeast Asia. Lo Spettatore Internazionale, 11(3), pp. 249-273. https://doi.org/10.1080/03932727608459075

Schwab, K., and Sala-i-Martin, X., 2013. The Global Competitiveness Report 2013-2014. World Economic Forum, Geneva, Switzerland.

Scott, B.R., and Lodge, G.C., 1985. U.S. competitiveness in the world economy. The International Executive, 27(1), pp. 26-26. https://doi.org/10.1002/tie.5060270112

Siudek, T., and Zawojska, A., 2014. Competitiveness in the economic concepts, theories and empirical research. Acta Scientiarum Polonorum. Oeconomia, 13(1), pp. 91-108.

The Global Competitiveness Report 2017-2018, 2017. World Economic Forum, Geneva.

Tiemstra, J.P., 1994. Competitiveness and industrial policy. International Journal of Social Economics, 21(8), pp. 30-42. https://doi.org/10.1108/03068299410065403

Tyson, L., and Zysman, J. (Eds.), 1983. American industry in international competition: government policies and corporate strategies. Cornell University Press, Ithaca.

Vlados, Ch., 2019a. The phases of the postwar evolution of capitalism: The transition from the current crisis into a new worldwide developmental trajectory. Perspectives on Global Development and Technology, 18(4), pp. 457-488. https://doi.org/10.1163/1569149712341528

Vlados, Ch., 2019b. Porter's diamond approaches and the competitiveness web. International Journal of Business Administration, 10(5), pp. 33-52. https://doi.org/10.5430/ijba.v10n5p33

Vlados, Ch. 2019c. Change management and innovation in the 'living organization': The Stra.Tech.Man approach. Management Dynamics in the Knowledge Economy, 7(2), pp. 229-56.

Vlados, Ch., 2006. Dynamics of globalization and the Greek enterprises. Book published in Greek

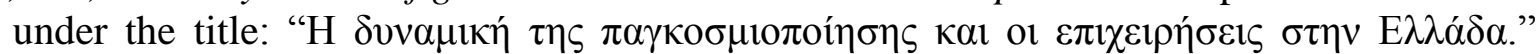
Kritiki Publications, Athens.

Vlados, Ch., 2004. La dynamique du triangle stratégie, technologie et management: L'insertion des entreprises grecques dans la globalisation (Thèse de doctorat de Sciences Économiques). Université de Paris X-Nanterre.

Vlados, Ch., 1996. International restructuring dynamics of competitive advantages. Middle East FORUM, (1) 233-252. https://doi.org/10.2139/ssrn.3217975

Vlados, Ch., and Chatzinikolaou, D., 2019. Methodological redirections for an evolutionary approach of the external business environment. Journal of Management and Sustainability, 9(2), pp. 25-46. https://doi.org/10.5539/jms.v9n2p25

Vlados, Ch., Deniozos, N., and Chatzinikolaou, D., 2019a. Global crisis and restructuring: Theory, analysis, and the case of Greece. KSP Books. https://doi.org/10.2139/ssrn.3433099

Vlados, Ch., Deniozos, N., and Chatzinikolaou, D., 2019b. Dialectical prerequisites on geopolitics and geo-economics in globalization's restructuration era. Journal of Economic and Social Thought, 6(2), pp. 65-92. https://doi.org/10.1453/jest.v6i2.1877

Warwick, K., 2013. Beyond industrial policy: emerging issues and new trends (OECD Science, Technology and Industry Policy Papers No. 2). OECD Publishing, Paris. https://doi.org/10.1787/5k4869clw0xp-en

Wren, C., 2001. The industrial policy of competitiveness: A review of recent developments in the UK. Regional Studies, 35(9), pp. 847-860. https://doi.org/10.1080/00343400120090266 
European Journal of Business and Innovation Research

Vol.8, No.1, pp.1-18, January 2020

Published by ECRTD-UK

Print ISSN: 2053-4019(Print), Online ISSN: 2053-4027(Online)

Acknowledgement: We would like to express our gratitude to Dr Andreas Andrikopoulos, Associate Professor at the Department of Business Administration of the University of the Aegean, who provided useful comments during the writing of this manuscript.

Note for the reader: This is an extended and enriched version of the article that the authors presented in the international scientific conference "ICABE 2019" under the title "Connection of competitiveness and industrial policy: Theoretical trends." 